\title{
ABL2 Gene Mutation
}

National Cancer Institute

\section{Source}

National Cancer Institute. ABL2 Gene Mutation. NCI Thesaurus. Code C150432.

A change in the nucleotide sequence of the ABL2 gene. 